\title{
Redescription of the Indo-Pacific Scorpionfish Scorpaenopsis fowleri and Reallocation to the Genus Sebastapistes ${ }^{1}$
}

\author{
Fobn E. Randall ${ }^{2}$ and Stuart G. Poss ${ }^{3}$
}

\begin{abstract}
The wide-ranging Indo-Pacific scorpionfish Scorpaenodes fowleri (Pietschmann), long placed in the genus Scorpaenopsis (largely because it lacks palatine teeth), is reclassified in the genus Sebastapistes. It is distinct from the species of Scorpaenopsis in several features: eye not extending above the dorsal profile of the head, large pores of the cephalic lateralis system, nasal pore above and adjacent to posterior nostril with a very small retrorse nasal spine (may be absent) on its upper edge, low ridgelike spines dorsally on the head, preocular spine usually embedded, sphenotic and postorbital spines absent or embedded; posterior lacrimal spine projecting slightly anteriorly, and a single spine posteriorly on the suborbital ridge with a pore-associated spine just below the ridge under the posterior third of the eye. Also significant is its very small size, the smallest of the Scorpaenidae (largest specimen, $37 \mathrm{~mm}$ SL; smallest mature female, $18 \mathrm{~mm} \mathrm{SL}$ ). The loss of palatine teeth appears to have occurred independently from the species of Scorpaenopsis. Sebastapistes fowleri is closest to $S$ strongia, the type species of the genus. In addition to having palatine teeth, $S$. strongia differs in the strongly retrorse posterior lacrimal spine and in having two spines on the suborbital ridge. The limits of Sebastapistes need reevaluation.
\end{abstract}

Pietschmann (1934:99) described a diminutive scorpionfish from O'ahu, Hawaiian Islands, as Scorpaena fowleri from three specimens that were deposited in the Naturhistorisches Museum in Vienna as NMw 6341-6343. Pietschmann (1938:5, 30, pl. 9) changed the generic allocation to Scorpaenodes and provided a redescription and illustration of the species.

Herre (1935:409; 1936:262, fig. 12) created the first synonym of fowleri with the description of Sebastapistes badiorufus, based on a single 22-mm specimen from Takaroa, Tuamotu Archipelago.

Fowler (1949:107) retained fowleri in the genus Scorpaenodes. He provided a basis for its separation from Scorpaenodes kelloggi (Jenkins),

\footnotetext{
${ }^{1}$ Manuscript accepted 15 May 2001.

2 Bishop Museum, 1525 Bernice Street, Honolulu, Hawai'i 96817-2704 (E-mail: jackr@hi.net).

${ }^{3}$ Ichthyology, California Academy of Sciences, Golden Gate Park, San Francisco, California 94118 (Email: sgposs@cableone.net).
}

Pacific Science (2002), vol. 56, no. 1:57-64

(C) 2002 by University of Hawai'i Press.

All rights reserved but suggested a closer affiliation with Sebastapistes asperella (Bennett).

Gosline and Brock (1960:342) regarded Scorpaena fowleri as a synonym of Scorpaena ballieui Sauvage (now classified in Sebastapistes), but with a question mark.

Klausewitz (1970:73, fig. 1) described Sebastapistes hassi from one specimen, $23.4 \mathrm{~mm}$ SL, from $38 \mathrm{~m}$ off Addu Atoll, Maldive Islands, the second junior synonym of fowleri.

Randall (1973:185) included fowleri as a species of Scorpaenopsis in a checklist of fishes of the Society Islands.

Eschmeyer and Randall (1975:297, fig. 13) designated NMw 6341 as the lectotype of Scorpaena fowleri and also reclassified it in Scorpaenopsis. They added, "Most of the species usually referred to Scorpaenopsis seem more closely related to each other than to the species in various subgroups of Scorpaena, but there are a few species which stand apart. They are usually placed in Scorpaenopsis because they lack palatine teeth. Among these are S. fowleri...."

Eschmeyer and Randall separated fowleri from other species of Scorpaenopsis by its possession of 16 pectoral rays instead of 17 or 
more, and by the posterior lacrimal spine that angles anteriorly. They extended the range of the species to the Tuamotu Archipelago (then unaware of Sebastapistes badiorufus from the Tuamotus), American Samoa, and the Marshall Islands and illustrated a specimen from the Society Islands.

Myers (1988:137) listed Scorpaenopsis fowleri as a first record from Guam, Mariana Islands.

Winterbottom et al. (1989:21) reported the species from the Chagos Archipelago, Indian Ocean.

Kosaki et al. (1991:189, fig. 6) provided the record from Johnston Island. They wrote, "This small species is placed in Scorpaenopsis primarily on the lack of palatine teeth; further study may result in its placement in a new genus."

Randall and Anderson (1993:11) reported an additional specimen of Scorpaenopsis fowleri from the Maldive Islands and listed Sebastapistes hassi Klausewitz as a synonym. They also indicated that fowleri does not fit well in Scorpaenopsis.

Kulbicki et al. (1994:17) recorded Scorpaenopsis fowleri from the Chesterfield Islands, Coral Sea; they enclosed Scorpaenopsis in quotation marks.

Randall (1996:62) illustrated Scorpaenopsis fowleri in color and proposed the common name Dwarf Scorpionfish. He also indicated that a new genus may be needed for the species.

Randall (1999:10) recorded the species from Oeno Atoll, Pitcairn Islands.

Myers (1999:98, pl. 26 G) illustrated Scorpaenopsis fowleri in color and gave the distribution as Comoro Islands to Oeno, north to the Philippines and Hawaiian Islands, and throughout Micronesia based on new localities from the fish collection of the California Academy of Sciences.

Scorpaenopsis Heckel, 1837, contains at least three distinct lineages, apart from $S$. fowleri. One is the humpback species, $S$. gibbosa, $S$. diabolus, S. neglecta, and S. macrochir. A second consists of large, more elongate, long-snouted species with a single upper opercular spine, such as $S$. cacopsis, S. cirrosa, S. oxycephala, and $S$. papuensis. The third includes small species with short snouts and the upper opercular spine divided into two or more points. Examples are $S$. altirostris, $S$. cotticeps, and $S$. gilchristi, all based on limited material. There are a few species that are allied with one of these lineages but differ enough to make their inclusion questionable, such as $S$. venosa in the second lineage and $S$. brevifrons in the third.

Scorpaenopsis fowleri has so many morphological differences from the above lineages of the genus that it clearly cannot be grouped with any of them. As is discussed in the following section, its closest affinity is with the genus Sebastapistes, of which the type species is $S$. strongia (Cuvier). We conclude that the loss of palatine teeth has occurred independently in fowleri and in the species of Scorpaenopsis.

\section{MATERIALS AND METHODS}

Specimens were examined at the Bernice P. Bishop Museum, Honolulu (врвм); California Academy of Sciences, San Francisco (CAS); Gulf Coast Research Laboratory Museum, Ocean Springs, Mississippi (GCRL); and National Museum of Natural History, Washington, D.C. (USNM).

Methods of taking measurements and the terminology of head spines follow Eschmeyer (1969) except that lacrimal is used instead of preorbital.

Sebastapistes fowleri (Pietschmann) Dwarf scorpionfish

Figures 1, 2

Scorpaena fowleri Pietschmann, 1934:99 (type locality, Makua, O'ahu, Hawaiian Islands).

Scorpaenodes fowleri Pietschmann, 1938:5, pl. 9 (redescription).

Sebastapistes badio-rufus Herre, 1935:409 (type locality, Takaroa Atoll, Tuamotu Archipelago); Herre, 1936:262, fig. 12.

Sebastapistes bassi Klausewitz, 1970:73-75, fig. 1 (type locality, Addu Atoll, Maldive Islands).

Scorpaena ballieui (non Sauvage) Gosline \& Brock, 1960:342 (Hawaiian Islands).

Scorpaenopsis fowleri: Eschmeyer and Randall, 1975:297, fig. 13 (Hawaiian Islands, Tua- 


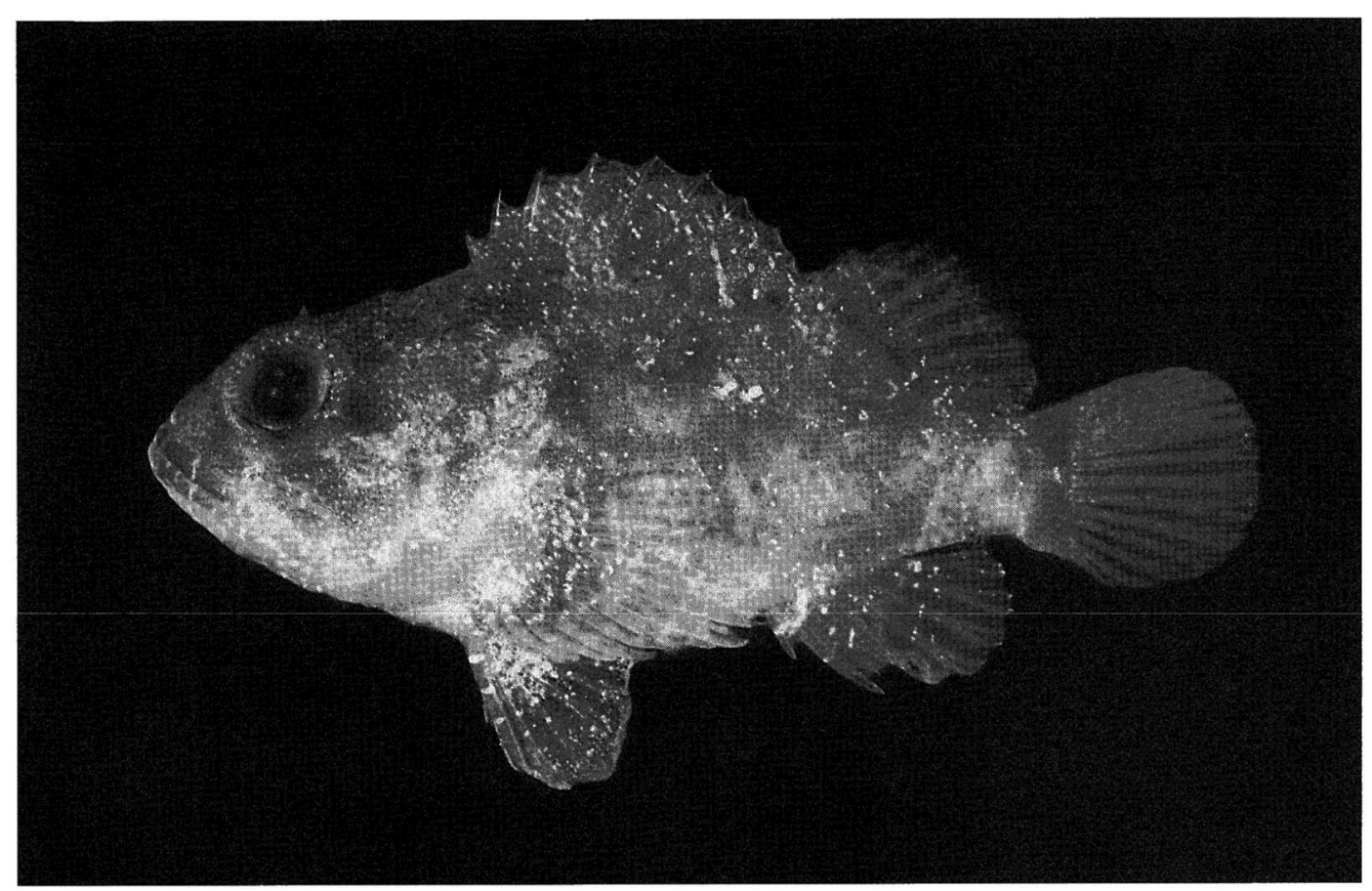

Figure 1. Sebastapistes fowleri, cas 30738, $27 \mathrm{~mm} \mathrm{SL}$, Kona coast of Hawai'i.

motu Archipelago, Society Islands, American Samoa, and Marshall Islands).

DESCRIPTION: Dorsal-fin rays XII,9 (last ray branched to base); anal-fin rays III, 5 (last ray branched to base); principal caudal rays 13 , the median 11 branched; pectoral rays 16 (all simple except branched tips found in upper rays of two specimens); pelvic-fin rays I,5; longitudinal scale series (in near-vertical rows) 32-34; lateral-line (pored) scales 21; 6 scales above front of lateral line to base of third dorsal spine; scales below lateral line to origin of anal fin 8-9; median predorsal scales 3; gill rakers $4-6+7-11$.

Body moderately deep, the depth 2.6-2.8 in SL; head length 2.15-2.4 in SL (head relatively shorter, in general, in larger specimens); snout very short, 3.7-4.2 in head length; eye not extending above dorsal profile of head (only the supraorbital ridge slightly above profile); orbit diameter 2.75-3.65 in head length; interorbital width 4.4-6.6 in head length; caudal-peduncle depth 7.2-7.8 in SL.
Mouth large, terminal or with lower jaw slightly projecting, the gape strongly oblique, the maxilla reaching posterior to a vertical at rear edge of pupil (usually to or slightly posterior to a vertical at rear edge of orbit); a villiform band of slender inwardly depressible teeth in jaws, the inner teeth longest (teeth in a maximum of about 5 irregular rows anteriorly in jaws); small slender teeth in two rows forming a V-shaped patch on vomer; no palatine teeth. Tongue triangular, the upper surface with small papillae. Gill rakers small, the longest a little shorter than longest gill filaments.

No occipital or suborbital pit. Spines dorsally on head ridgelike and retrorse; parietal spine about twice as long as tympanic and nuchal spines; nasal spine small (sometimes absent), over posterior nostril; preocular spine usually embedded; no coronal spines; sphenotic spines absent or embedded; no postorbital spines; cleithral spine short and nearly flat, forming an angle of nearly $45^{\circ}$ to horizontal axis of head and body; lacrimal with 
two spines that project ventrally over maxilla when mouth closed, the posterior one angling slightly anteriorly; suborbital ridge with a single flat spine at posterior end; an isolated flat spine just below suborbital ridge beneath posterior third of eye; upper preopercular spine without a supplemental spine or with only a protuberance or small spine on its anterior edge; two low ridges with pointed tips between posterior end of parietal spine and posttemporal spines; upper opercular spine single; lower opercular spine preceded by a ridge.

Nostrils at level of upper edge of pupil, the anterior in a short flaring membranous tube with a slender dorsoposterior flap that reaches a little beyond posterior nostril when laid back; posterior nostril large, at edge of orbit directly behind anterior nostril, with a low rim at front.

Prominent sensory pores of cephalic lateralis system as follows: nasal pore dorsoanterior to posterior nostril and separated from it by a narrow septum, usually with the small nasal spine just above; a transverse pair of interorbital pores; a pore beneath slightly elevated tympanic spine, and one beneath tip of lower posttemporal spine; three in channel below nuchal spine, one above and another below embedded sphenotic spine or spines; eight along edge of preopercle, and four on mandible; four large pores in lacrimal and three in suborbital ridge (one associated with small spine below posterior part of eye and one at each bifurcating tip of channel at posterior end of ridge).

Cirri and tentacles typically few and small; supraocular tentacle present (may be very small).

Scales ctenoid on most of body, becoming cycloid on abdomen, chest, and prepectoral region; scales on head only on nape posterior to nuchal spines and dorsally on opercle; small scales basally on caudal fin and soft portions of dorsal and anal fins; lateral line complete, the anterior scales with a small spine at end of sensory tube.

First dorsal spine about half length of second spine; second dorsal spine half to twothirds length of third spine; fourth or fifth dorsal spines longest, 5.2-6.3 in SL; eleventh dorsal spine about half length of twelfth spine; longest dorsal soft ray 4.5-5.7 in SL; three-fourths or more of last dorsal ray joined by membrane (when intact) to caudal peduncle; second anal spine usually longest (sometimes about equal to third spine), its length 5.1-5.8 in SL; caudal fin small and rounded, $3.4-4.25$ in SL (relatively longer in smaller specimens); pectoral fins rounded, the middle rays longest, $3.1-3.9$ in SL; lower 7 or 8 pectoral rays thicker than upper rays; second or third pelvic soft ray longest, its length 3.23.95 in SL; three-fourths or more of last pelvic ray joined by membrane to abdomen.

Color in alcohol usually entirely pale yellowish except for dusky basal three-fifths of pelvic fins. Occasional specimens with dark markings as follows: an irregular dusky oblique bar extending below middle of spinous portion of dorsal fin, and a broad one between soft portions of dorsal and anal fins, extending onto anal fin; several small dark spots sometimes present along base of dorsal fin; an irregular dark bar passing ventrally from eye, and an oblique band across part of cheek from posteroventral part of eye; scaled basal part of caudal fin dusky; outer part of fin broadly dusky or with narrow vertical bars that are darker on rays than membranes; pectoral fins with two irregular transverse bands; basal three-fifths of pelvic fins dusky to dark brown (darkest of all the markings).

Color in life red to reddish orange, finely mottled with white, often with dark markings as described above.

REMARKs: Proportional measurements of Sebastapistes fowleri are based on 12 specimens, 16-36 mm SL.

Only two specimens were found with branched pectoral rays, a $28-\mathrm{mm}$ one from Oeno Atoll, Pitcairn Islands, with the tips of three of the upper rays branched, and a 36$\mathrm{mm}$ one from O'ahu, Hawaiian Islands, with the the tip of the fifth ray branched on one side.

The most important characters that separate fowleri from the species of Scorpaenopsis are the following: eye not extending above dorsal profile of head; pores of cephalic lateralis system large (those of Scorpaenopsis numerous and minute except for mandibular 
pores); spines dorsally on head low and ridgelike (spines prominent and project obliquely upward in Scorpaenopsis); posterior lacrimal spine retrorse, suborbital ridge with a single posterior spine (three to five in Scorpaenopsis); preocular spine embedded; sphenotic spines absent or embedded; and postorbital spines absent.

The small size of Scorpaenopsis fowleri prompted a comparison with the Indo-Pacific genus Sebastapistes Gill, of which 11 species are currently known, including four that are undescribed These species are small with a short snout, the eye not elevated, and they have low modal pectoral-ray counts of 15 or 16. Sebastapistes strongia is the most similar to fowleri. The spines dorsally on the head of that species are low, though not as ridgelike as in fowleri. It has prominent cephalic sensory pores like fowleri. The nasal spine is small, retrorse, and over the posterior nostril, with the small nasal pore between (the spine is not as small and not as close to the nasal pore as in fowleri). There is a spine just below the suborbital ridge associated with a pore, and there are two lacrimal spines that project over the maxilla. Sebastapistes strongia differs in having palatine teeth, the second lacrimal spine projecting strongly posteriorly, and two spines on the suborbital ridge, in addition to the one just below. Lesser differences of strongia include modally 15 pectoral rays, about 44 scales in longitudinal series, usually well-developed tentacles, especially the supraocular, and transverse dark bands ventrally on the head.

Sebastapistes strongia and S. fowleri share the large pores of the cephalic lateralis system, the low spines dorsally on the head, the long parietal spine, and the isolated spine below the suborbital ridge with $S$. galactacma Jenkins and the four undescribed species of the genus (three of which, like galactacma, have cycloid scales). The four other species currently placed in Sebastapistes lack large cephalic sensory pores, have more strongly developed and more erect spines on the head, and the parietal spine is about equal in length to the tympanic and nuchal spines. Sebastapistes ballieui (Sauvage) and S. mauritiana (Cuvier) differ further in having prominent coronal spines, and S. coniorta (Jenkins) and S. tinkbami (Fowler) have three to five lacrimal spines instead of two, and the lower opercular spine is preceded by a scaled area without a distinct ridge. Therefore, there seems to be three lineages within the genus Sebastapistes. Further study is needed to determine if all should remain in Sebastapistes.

Sebastapistes fowleri is wide-ranging in the Indo-Pacific region, from the Pitcairn Islands and Hawaiian Islands to Mauritius and the Comoro Islands. It generally occurs on rubble or rubble and sand substrata within or near coral reefs. Of the 20 lots in the Bishop Museum for which there are data on the depth of capture, all but one were taken in more than $10 \mathrm{~m}$. The specimen from a shallower station was collected from $4.5-6 \mathrm{~m}$. The deepest collection was from $61 \mathrm{~m}$ at Tetiaroa Atoll, Society Islands. Of 33 lots of this species from CAS and USNM collections with depth data, 23 were from $10-43 \mathrm{~m}$, six from 6-9 $\mathrm{m}$, and four from about $3 \mathrm{~m}$.

The largest of 42 specimen examined, 37 $\mathrm{mm}$ SL, was taken at Oeno Atoll, Pitcairn Islands; the second largest, $36 \mathrm{~mm}$, at $\mathrm{O}^{\prime} \mathrm{ahu}$. Both localities are subtropical.

Eschmeyer and Randall (1975:298) wrote, "This species almost certainly matures at the smallest size (about $25 \mathrm{~mm}$. S. L.) of any scorpaenid now known." We have found a fully mature female even smaller, врвм 21836, $18 \mathrm{~mm}$ SL, from Mauritius.

MATERIAL EXAMINED: HAWAIIAN ISLANDS: Hawai'i, CAS 30738, $27 \mathrm{~mm}$; GCRL 31910, 2: 18-24 mm. O'ahu, врвм 7853, 25 $\mathrm{mm}$; вРвм 7854, $27 \mathrm{~mm}$; вРвм 17812, 2: 20 $26 \mathrm{~mm}$; вРвм 28138, 5: 26-36 mm; вРвм 28141, 3: 27-34 mm; CAS 30738, $25.5 \mathrm{~mm}$; CAS 54091, 2: 22-25.5 mm; GCRL 31911, 11: 21.5-34 mm. JOHNSTON ISLAND: врвм 33999, $20 \mathrm{~mm}$. PITCAIRN ISLANDS: Oeno Atoll, врвм 11181, 7: 24-37 mm. TUAMOTU ARCHIPELAGO: Mangareva, вРвм 13576, 2: 16-24 mm; врвм 29328, 2: 16-16.5 mm. Anaa Atoll, врвм 16434, $22 \mathrm{~mm}$. Takaroa Atoll, врвм 11159, $22.5 \mathrm{~mm}$. Malremo, USNM 66026, $19.5 \mathrm{~mm}$. SOCIETY ISLANDS: Tetiaroa Atoll, врвм 14968, $23 \mathrm{~mm}$. Tahiti, врвм 5865, 19.5 $\mathrm{mm}$; врвм 6938, $20.5 \mathrm{~mm}$; врвм 8367, 22.5 


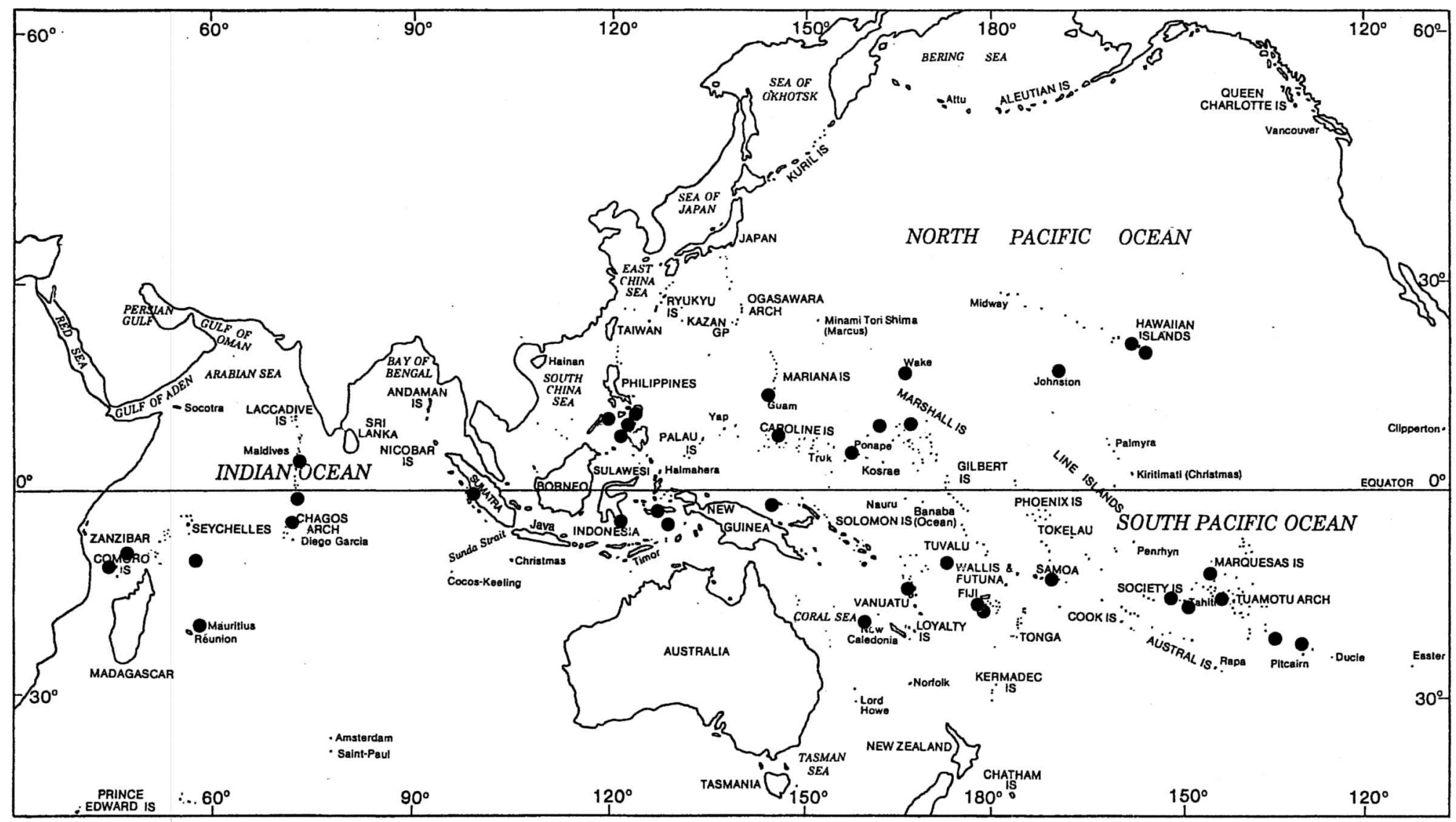

FIGURE 2. Distribution of Sebastapistes fowleri. 
mm. Raiatea, cAs 54093, $19.5 \mathrm{~mm}$. AMERICAN SAMOA: Tutuila, врвм 17246, 21.5 mm; вРвм 18720, 3: 13-23 mm; GCRL 23540, $18.8 \mathrm{~mm}$. FIJI: USNM 26652, 10: $12.5-24.5$ mm; USNM 266254, 6: 15-24 mm; USNM 26656-26657, 5: 15.5-24 mm. Matuku Island, cas 54094, 21: 14-25 mm; cas 54102, 4: 16-25 mm; USNM 266254, 6: 17.5-24 mm. Kandavu, cas 54095, 3: 15-18 mm. Ono-ilau, CAS 54096. $21 \mathrm{~mm}$; CAS 54099, $13 \mathrm{~mm}$. Navatu Ira Island, CAS 54097, 2: 15-21 mm; CAS $54100,11 \mathrm{~mm}$. Toyoda, USNM 266357, 4: 16$24 \mathrm{~mm}$. Lau Group, Yangasa Cluster, cAS 54098, $17 \mathrm{~mm}$. Viti Levu, врвм 28656, 21.5 mm; CAS 54101, 7: 12-27 mm; USNM 266256, $22.5 \mathrm{~mm}$. Malolo, cAs 54103, $15 \mathrm{~mm}$. ROTUMA: CAS 60221, 13 mm. MARSHALL ISLANDS: Enewetak Atoll, врвм 8287, 2: 24-25 mm; врвм 18420, $20 \mathrm{~mm}$; сAS 31807, $23.5 \mathrm{~mm}$; CAS 31808, $24.5 \mathrm{~mm}$. Rongelap Atoll, cas 43013, $26.5 \mathrm{~mm}$; cas 54092, 21.5 mm; USNM 140184, $23.5 \mathrm{~mm}$. CAROLINE ISLANDS: Pohnpei (Ponape), UsNM 224486, 4: 11-20.5 mm; USNM 224487, 2: 16-20 mm; USNM 224489, 5: 8-17 mm. Ifaluk Atoll, cAs 54089, $22 \mathrm{~mm}$; CAS 54090, $19 \mathrm{~mm}$. WAKE ISLAND: врвм 38593, $23 \mathrm{~mm}$. CORAL SEA: Chesterfield Islands, врвм 33810, 4: 23-26.5 mm. VANUATU: Espiritu Santo, USNM 285932, $28 \mathrm{~m}$. MARIANA ISLANDS: Guam, вРвм 8446, 21 mm; GCRL 31909, 3: 17-21.5 mm. PAPUA NEW GUINEA: Ninigo Islands, USNM 266261, 2: 21.5-24.5 mm. INDONESIA: Banda, USNM 266113, $16.5 \mathrm{~mm}$. Saparua, USNM 266114, 6: 13-25 $\mathrm{mm}$. Ambon, USNM 265922, $21 \mathrm{~mm}$. Kabaena, UsNM 266115, $20.5 \mathrm{~mm}$. Sumatra, off Padang, врвм 37628, $20 \mathrm{~mm}$. PHILIPPINES: Mindanao, Zamboanga del Norte, cas 54084, 3: 21-24 mm; CAS 54088, $22 \mathrm{~mm}$. Siquijor, USNM 266251, 4: 21.5-22.5 mm. Negros, USNM 266250, $24 \mathrm{~mm}$; USNM 266255, 28-29.5 $\mathrm{mm}$; USNM 266260, $21.5 \mathrm{~mm}$. Cebu, CAS 54086, $23 \mathrm{~mm}$. Palawan, Cuyo Islands, USNM 266249, $23.5 \mathrm{~mm}$. Samar, cAs 54085, $23 \mathrm{~mm}$. MALDIVE ISLANDS: Addu Atoll, smF 9860, $22.4 \mathrm{~mm}$ (holotype of Sebastapistes bassi). North Malé Atoll, врвм 32988, 21.5 mm. MAURITIUS: вPвм 21836, $18 \mathrm{~mm}$. AGALEGA ISLANDS: USNM 266021, 19.5 mm; USNM 266332, $18.5 \mathrm{~mm}$; USNM 266253,
$15 \mathrm{~mm}$. SEYCHELLES: Aldabra, USNM 264191, $12 \mathrm{~mm}$. COMORO ISLANDS: Grande Comore, cas 34887, 3: 13-19 mm.

\section{ACKNOWLEDGMENTS}

We thank Jon Fong of the California Academy of Sciences and Lisa Palmer of the National Museum of Natural History for curatorial assistance. Matthew Bleich of the Gulf Coast Research Laboratory assisted with the radiography. William N. Eschmeyer reviewed the manuscript.

\section{Literature Cited}

Eschmeyer, W. N. 1969. A systematic review of the scorpionfishes of the Atlantic Ocean (Pisces: Scorpaenidae). Occas. Pap. Calif. Acad. Sci. 27:iv + 130 .

Eschmeyer, W. N., and J. E. Randall. 1975. The scorpaenid fishes of the Hawaiian Islands, including new species and new records (Pisces: Scorpaenidae). Proc. Calif. Acad. Sci., ser. 4, 50 (11): 265-334.

Fowler, H. W. 1949. The fishes of OceaniaSupplement 3. Mem. B. P. Bishop Mus. 22 (2): 1-187.

Gosline, W. A., and V. E. Brock. 1960. Handbook of Hawaiian fishes. University of Hawai'i Press, Honolulu.

Herre, A. W. 1935. New fishes obtained by the Crane Pacific Expedition. Field Mus. Nat. Hist. Zool. Ser. Publ. 18 (12): 383438.

. 1936. Fishes of the Crane Pacific Expedition. Field Mus. Nat. Hist. Zool. Ser. Publ. 21:1-472.

Klausewitz, W. 1970. Sebastapistes bassi n. sp. von den Malediven (Pisces: Scleropareiformes: Scorpaenidae). Senckenb. Biol. $51(1 / 2): 73-75$.

Kosaki, R. K., R. L. Pyle, J. E. Randall, and D. K. Irons. 1991. New records of fishes from Johnston Atoll, with notes on biogeography. Pac. Sci. 45:186-203.

Kulbicki, M., J. E. Randall, and J. Rivaton. 1994. Checklist of the fishes of the Chesterfield Islands (Coral Sea). Micronesica 27 (1/2): 1-43. 
Myers, R. F. 1988. An annotated checklist of the fishes of the Mariana Islands. Micronesica $21(1 / 2): 115-180$.

1999. Micronesian reef fishes. Coral Graphics, Guam.

Pietschmann, V. 1934. Drei neue Fische aus den Hawaiischen Küstengewåssern. Anz. Akad. Wiss. Wien 71:99-100.

. 1938. Hawaiian shore fishes. Bernice P. Bishop Mus. Bull. 156:1-55.

Randall, J. E. 1973. Tahitian fish names and a preliminary checklist of the fishes of the Society Islands. Occas. Pap. Bernice Pauahi Bishop Mus. 24 (11): 167214.
1996. Shore fishes of Hawaii. Natural World Press, Vida, Oregon. 1999. Report on fish collections from the Pitcairn Islands. Atoll Res. Bull. 461:136.

Randall, J. E., and R. C. Anderson. 1993. Annotated checklist of the epipelagic and shore fishes of the Maldive Islands. Ichthyol. Bull. J. L. B. Smith Inst. Ichthyol. 59:1-47.

Winterbottom, R., A. R. Emery, and E. Holm. 1989. An annotated checklist of the fishes of the Chagos Archipelago, central Indian Ocean. R. Ont. Mus. Life Sci. Contrib. 145:vi + 226. 